\title{
HOW INITIAL COMPOSITION AFFECTS THE LATER DEVELOPMENT? - A SECONDARY SUCCESSIONAL STUDY IN DIFFERENTLY MANAGED AGRICULTURAL SITES
}

\author{
NAGY, D. U. ${ }^{1 *}-$ HenN, T. ${ }^{1,2}-$ WALLER, L. P. ${ }^{3}-$ PAL, R. W. ${ }^{1,4}$ \\ ${ }^{1}$ Department of Ecology, University of Pécs \\ Ifjúság útja 6, 7624 Pécs, Hungary \\ (phone: +36-72-503-600/24864) \\ ${ }^{2}$ City Government of Komló, József Attila Library and Museum Collection \\ Városház tér 1, 7300 Komló, Hungary \\ (phone: +36-72-481-071/7) \\ ${ }^{3}$ Division of Biological Sciences, University of Montana, \\ Missoula, MT 59812, USA \\ ${ }^{4}$ Biological Sciences, Montana Tech of the University of Montana, Butte, MT 59701, USA \\ *Corresponding author \\ e-mail: davenagy9@gmail.com \\ (Received $2^{\text {nd }}$ June 2015; accepted $4^{\text {th }}$ May 2016)
}

\begin{abstract}
Plant succession is a well-studied phenomenon in plant ecology, yet the effects of disturbance and its influence on initial plant composition received little attention in this process. From many of the potential reasons we investigated the effect of soil fungi on early succession. At each site a total of 60 permanent plots were established and fungicide treatment was used on half of the plots, the other half served as control. We found that management by influencing initial plant communities, determine the way how forb and grass dominancy changes in time. In addition, our findings support that the applied fungicide treatment influence successional development of plant communities. Specifically, the elimination of fungi from an annual-dominated (highly disturbed) site led to stronger grass dominance, while decreased the presence of forbs. Nevertheless in the perennial-dominated (less disturbed) site fungicide treatments favored to forbs, but this effect was not significant. Our results suggest that previously used management regimes strongly affect the later secondary successional events that can also be strongly influenced by the soil fungal community.
\end{abstract}

Keywords: fungicide, grassland, secondary succession, disturbance, soil, annual, perennial ratio

\section{Introduction}

Succession is a well-studied process in ecology (Van der Putten et al., 2000). The term refers to the development of species composition in a community, which is associated with a sequence of changes in its structural and functional properties (Drury and Nisbet, 1973). Following abandonment, there is a large number of arable fields in Europe, where developmental processes appear, thus it is unequivocal that several studies have focus on secondary succession in these habitats (Collins, 2001; Rehounková, 2010). In these studies, successional processes tended to return plant communities to the state they were in prior to disturbance (Horn, 1974). In the last decades, the effect of disturbance has been a major topic in succession studies (Perry and Millington, 2008; Prach et al., 2014), suggesting that disturbance is a main driving factor in vegetation changes. Nevertheless, disturbance-induced changes in the 
biophysical environment are related to disturbance size (Dölle and Schmidt, 2009, Burt and Clary, 2015). Different disturbance history creates different circumstances, which alter the way of plant communities' development. From this aspect the initial status of communities can play a major role in succession processes.

Soil biota is another important factor influencing the successional development of plant assemblages. Soil mutualists and pathogenic microorganisms are crucial in early stages of both primary and secondary successions by influencing many important ecosystem processes. Including direct effects like supporting or impairing plants (Rillig and Mummey, 2006; van der Heijden et al., 2008); and indirect effects, like the altering of nutrient cycles (nitrogen, carbon) and soil formation.

One of the most important positive relationship between plant species and soil fungi, is the mycorrhizal connection. A large number of papers have dealt with the effects of mycorrhizal fungi on individual plant species (Emery and Rudgers, 2012; Rydlová et al., 2015), but also there is a growing number of studies that reveal their role in shaping natural plant communities (van der Heijden et al., 1998). A diverse soil community can increase species richness and productivity of the vegetation (Schnitzer et al., 2010), moreover soil fungi not only affects the diversity of biosystems, but also controls succession. They are very important determinants on the earlier successional phase by stabilizing perennial forb seedlings (Gange et al., 1993). It triggers this effect by reducing competition among species that facilitate coexistence in the critical phase of community development (Mariotte et al., 2013). Furthermore there are evidences showing that, not only the vegetation can change during succession, but simultaneously soil fungal community, suggesting a sensitive feed-back between plants and soil fungi ( Sikes et al., 2012, Cutler et al., 2014).

In contrast, negative influences of soil fungi on plants control the later diversification of developing plant communities by species replacements (Reynolds et al., 2003). With negative feedback soil fungi can maintain plant species diversity within a community, by reducing the dominance of certain species (Mills and Bever, 1998). The presence or absence of certain soil biota can also explain why some exotic plant species are able to occur at higher abundance in the non-native versus native range. Maron et al., (2014) found that soils from the native range of some invasive plant species had a strong suppressive potential on these plants, whereas this is not the case in soils in the nonnative range. This suggests that different composition of soil community can strongly alter the structure of vegetation.

Besides the previously mentioned direct effects, indirect effects of soil fungi could also be crucial in shaping community composition. Higher microbial biomass may negatively influence plant communities in competition for nutrients (Dunn et al., 2006). Another way for fungi to reduce available soil nutrients is by transforming them. Certain denitrifying fungi can transform nitrate into $\mathrm{N}$ gases causing high loss of soil nitrogen content (Waring et al., 2013).

During our research we tested the indirect effects of combined fungicide treatment on plant community composition of two differently managed sites, which were dominated by annual forbs or perennial forbs, and asked the following questions: a.) how does successional development differ in plant communities with different initial disturbance history; b.) what is the effect of the elimination of soil fungi on the species composition in different successional stages? 


\section{Materials and methods}

\section{Field experiment}

We performed our field experiments from 2008 to 2011, at two differently managed sites in South Western Hungary. One of our sites (near the town of Siklós; coordinates: $45.881500,18.254238)$ was a recently (2-3 years) abandoned vineyard (area $7.000 \mathrm{~m}^{2}$ ) in which seasonal management still occurred (hoeing, mowing). We called this site annual-dominated, because, the site was dominated mainly by annuals (Stellaria media, Lamium purpureum, Bromus sterilis, Arenaria serpyllifolia, Vicia angustifolia) and some perennials (Elymus repens, Poa pratensis; Appendix Table 1). The second site (near the town of Máriakéménd; coordinates: 46.026577, 18.470698) was a diverse meadow steppe (area $16.000 \mathrm{~m}^{2}$ ), that was also actively managed as an orchard 30 years ago and is now mown once a year. The site is called perennial-dominated, because the site was dominated mainly by perennials (Achillea collina, Agrimonia eupatoria, Calamagrostis epigeios, Centaurea stoebe, Coronilla varia, Dactylis glomerata, Euphorbia cyparissias, Galium mollugo, Knautia arvensis, Poa angustifolia, Scabiosa ochroleuca, Appendix Table 2). Both sites had similar geographic and climatic conditions. The region is hilly $(120-180 \mathrm{~m})$ with an average elevation of $150 \mathrm{~m}$. The mean annual precipitation is $650-700 \mathrm{~mm}$ and the mean annual temperature is $10-11^{\circ} \mathrm{C}$ (averages between 1971-2000) (Bihari et al., 2009).

In both sites, we selected $60(50 \times 50 \mathrm{~cm})$ fixed position quadrates for four years. Position of the quadrates was designated semi-systematically; both sites were divided into 60 equal sized blocks grid $\left(85 \mathrm{~m}^{2}\right.$ in the annual-dominated and $270 \mathrm{~m}^{2}$ in the perennial-dominated sites), and in each blocks one quadrate were posited randomly. In the first year we surveyed the baseline conditions of the quadrates (created a species list, estimated the cover of forbs and grasses, along with the estimation of bare ground and leaf litter). Scientific names of plant species follow Király (2009). From the beginning of the experiment we excluded every kind of management in the fields, for being able to observe successional differences. To detect the effects of soil fungi on the development of plant communities we applied a Mefenoxam $(56,304 \mathrm{mg} / \mathrm{l})$ and Thiophanate-methyl $(1250 \mathrm{mg} / \mathrm{l})$ fungicide mixture on half of the plots (30). The other half of the plots served as control. The fungicide treatment was applied twice a year in spring and in summer. Each treated plot received $250 \mathrm{ml}$ of the fungicide mixture while control plots received the same amount of water.

We collected data from the plots once a year, in late spring (around May). In each plot, the number of all vascular plant species was recorded and their coverage (\%) estimated. We also estimated litter coverage and bare ground surface. We distinguished two groups of vascular plants, (grasses and forbs) for the statistical analysis.

\section{Data analysis}

For the statistical analysis we carried out built linear model for each measured parameters, using function $1 m$ (based on Chambers, 1992) in $R$ environment ( $R$ version 2.15.1; R Development Core Team, 2011), function anova were used to visualize ANOVA table. The models also included two and three-way interactions. Our dependent variables were the measured attributes (coverage of grasses, forbs, leaf litter and bare ground), while the independent variables were the fungicide treatment, disturbance, and year. All independent variables were treated as fixed factors and were $\log$ transformed. Transformation was based on graphical evaluation according to 
Crawley (2014). For pair-wise comparisons, Tukey post-hoc tests were conducted in both cases with multcomp-package (Hothorn et al., 2008).

\section{Results}

We detected significant differences between the field sites with different initial plant dominancy (Appendix Table 1 and 2). The results of the ANOVA are shown in Table 1.

The coverage of forb species differed highly at the initial stage, depending on the management regime of the plant community (Figure 1). Significantly higher (16\%) dominance of forbs were detected at the annual-dominated site compared to the perennial-dominated one $(\mathrm{t}=-4.163 ; \mathrm{P}<0.01)$. In the following two years a different trend was detected at both places: at the annual-dominated site we registered decreasing dominance of forbs, while at the perennial-dominated site their dominance increased. During this period the differences between the two sites disappeared. In the fourth year the tendencies strengthened and showed stronger significant differences between the sites $(35 \%)(t=9.40800 ; \mathrm{P}<0.001)$. In the perennial-dominated site, the coverage of forbs became higher than in the annual-dominated site by $40 \%$. The fungicide treatment did not cause differences in the first three years, but at the fourth year the elimination of soil fungi affected forbs positively the annual-dominated site $(14 \%)(\mathrm{t}=-3.708 ; \mathrm{P}=$ $0.0204)$. In the non-fungicided quadrates the number of forbs significantly decreased by $30 \%$ during the three years of the experiment, at the same time the fungicide treatment moderated the loss of forb coverage.

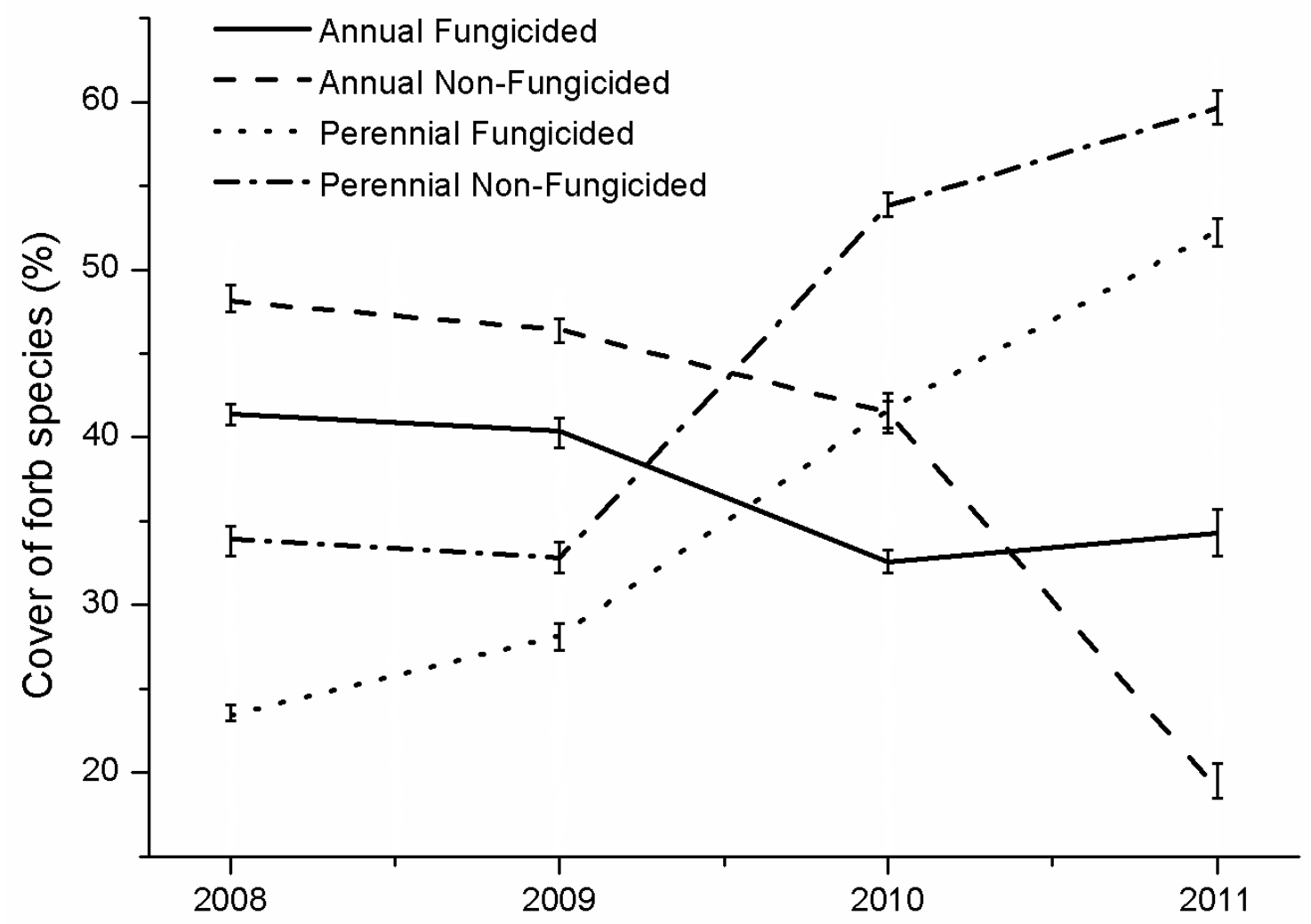

Figure 1. Changes in the coverage of forb species from 2008-2011. Error bars represent S.E.M. 
Table 1. ANOVA results of the applied linear models of the effects of different sites (annual-dominated and perennial-dominated), fungicide treatment and time on the forb cover, grass cover, bare ground cover, and leaf litter cover.

\begin{tabular}{|c|c|c|c|c|c|c|c|c|c|c|c|c|}
\hline & \multicolumn{3}{|c|}{ Forb cover $(\%)$} & \multicolumn{3}{|c|}{ Grass cover $(\%)$} & \multicolumn{3}{|c|}{ Bareground (\%) } & \multicolumn{3}{|c|}{ Leaf litter $(\%)$} \\
\hline & $\mathrm{df}$ & F-value & $\mathrm{P}$ & df & F-value & $\mathrm{P}$ & $\mathrm{df}$ & F-value & $\mathrm{P}$ & df & F-value & $\mathrm{P}$ \\
\hline Site & 1 & 5.894 & $0.0155 *$ & 1 & 49.425 & $6.68 \mathrm{e}-12 * * *$ & 1 & 3.5749 & $0.028719 *$ & 1 & 598.018 & $<2,2 \mathrm{e}-16 * * *$ \\
\hline Fungicide treatment & 2 & 13.198 & $2.58 \mathrm{e}-06 * * *$ & 2 & 21.602 & $9.91 \mathrm{e}-10 * * *$ & 2 & 1.568 & 0.211080 & 2 & 6.667 & $0.00139 * *$ \\
\hline Year & 3 & 10.597 & $9.07 \mathrm{e}-07 * * *$ & 3 & 3.978 & $0.00807 * *$ & 3 & 13.380 & $2.04 \mathrm{e}-08 * * *$ & 3 & 16.388 & $3.52 \mathrm{e}-10 * * *$ \\
\hline Site:Year & 3 & 52,7877 & $<2,2 \mathrm{e}-16 * * *$ & 3 & 73.510 & $<2,2 \mathrm{e}-16 * * *$ & 3 & 52.048 & $<2,2 \mathrm{e}-16 * * *$ & 3 & 370.456 & $<2,2 \mathrm{e}-16 * * *$ \\
\hline Treatment:Year & 6 & 2.420 & $0.0257 *$ & 6 & 2.601 & $0.01716 *$ & 6 & 3.921 & $0.000767 * * *$ & 6 & 0.999 & 0.42517 \\
\hline Site:Treatment:Year & 15 & 13,069 & $<2,2 \mathrm{e}-16 * * *$ & 15 & 21,451 & $<2,2 \mathrm{e}-16 * * *$ & 15 & 23,211 & $<2,2 \mathrm{e}-16 * * *$ & 15 & 46,772 & $<2,2 \mathrm{e}-16 * * *$ \\
\hline
\end{tabular}

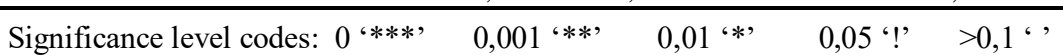


The grass coverage showed contrary results to the forbs (Figure 2). In the annualdominated site the dominance of grasses were low, while at the perennial-dominated site they were significantly $(11 \%)$ higher $(t=3.606 ; P=0.0292)$. In the second year of the experiment these differences further increased $(20 \%)(\mathrm{t}=4.591 ; \mathrm{P}<0.001)$. Namely at the perennial-dominated site the coverage of grasses increased while at the more disturbed site it decreased. In the third year we did not experience changes at the perennial-dominated site, but detected strong increase in grass coverage at the annualdominated site. In the fourth year of the experiment the dominance of grasses at the highly disturbed annual-dominated site increased further, while at the perennialdominated site it strongly decreased, causing significant differences between the two sites $(34 \%)(\mathrm{t}=-6.128 ; \mathrm{P}<0.001)$. The fungicide treatment did not cause differences during the first three years, but in the fourth year a significant effect was detected at the annual-dominated site $(\mathrm{t}=4.195 ; \mathrm{P}<0.01)$. The elimination of soil fungi caused lower increase $(15 \%)$ of grass dominance than in the control plots.

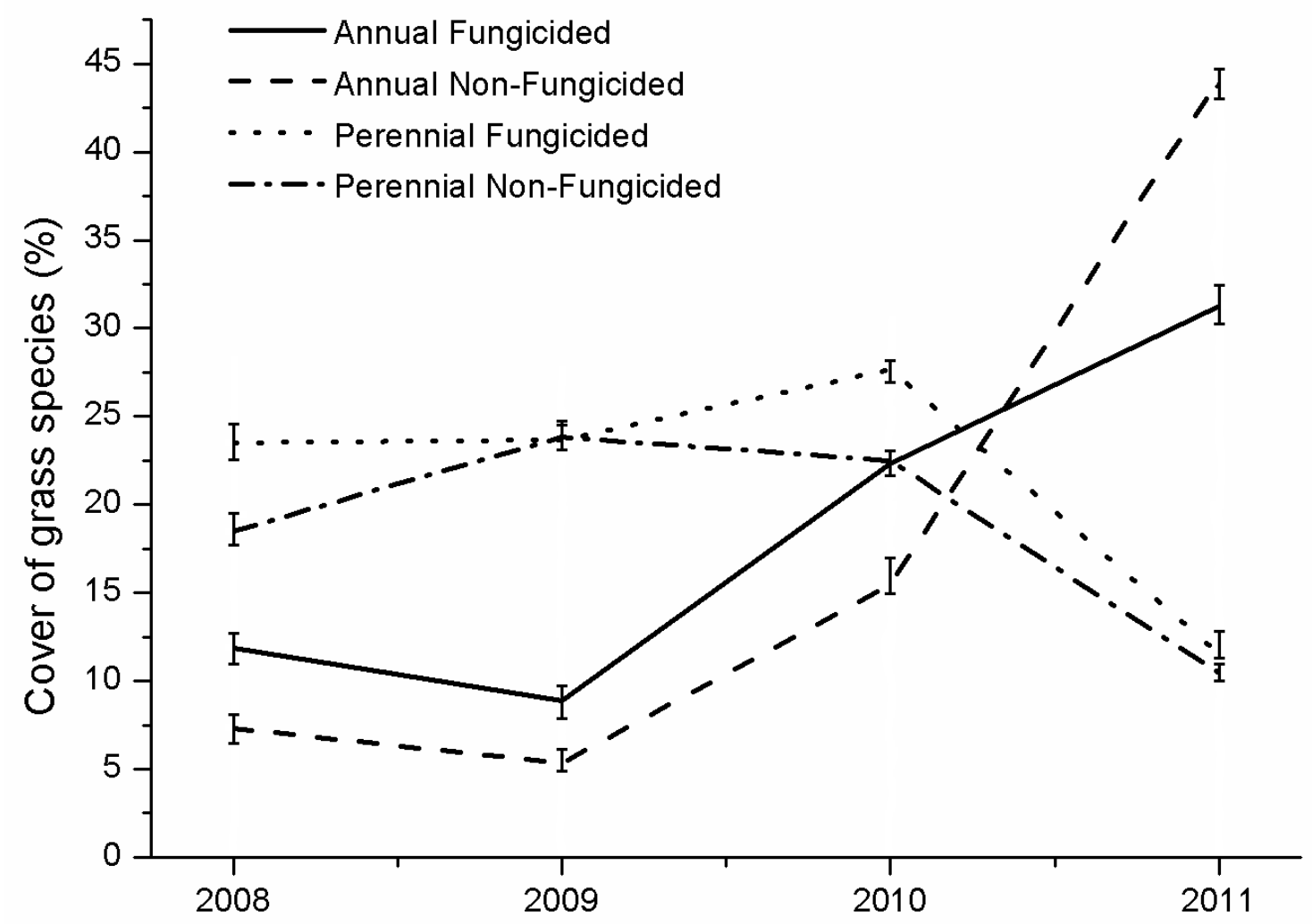

Figure 2. Changes in the coverage of grass species from 2008-2011. Error bars represent S.E.M.

The number of species changed at both sites significantly. In the second year the number of species on perennial-dominated site did not change, but in the third year it increased significantly by three new colonizer (Crepis biennis, Rosa canina, Scabiosa ochroleuca) $(\mathrm{t}=-5.5284 ; \mathrm{P}<0.001)$. In the last year no differences were detected. At the annual-dominated site the number of species increased significantly in the first two year, while stagnated at the last two years. Fungicide treatment did not affect this attribute at any of the experimental sites. 
Changes in bare ground surface were also observed (Figure 3). The two sites significantly $(27 \%)$ differed in their initial stage $(\mathrm{t}=-8.109 ; \mathrm{P}<0.01)$. At the perennialdominated field the coverage of bare ground was low at the first year, while it was high at the annual-dominated site due to the frequent management. In the second year of the experiment we recorded changes at both sites. At the annual-dominated site bare ground decreased by $7 \%$, but at the perennial-dominated site it increased by $17 \%$. The development of the two experimental sites was different. The bare ground at the annualdominated site reduced from year to year down to $0 \%$. At the perennial-dominated site the coverage decreased at the third year, and at the fourth year it increased again. We did not detect differences between the two sites at the second and third year, but there was a significant $(12 \%)$ difference $(\mathrm{t}=3.573 ; \mathrm{P}=0.0331)$ in the fourth year of the experiment. The fungicide treatment caused no differences in this attribute at any of the sites.

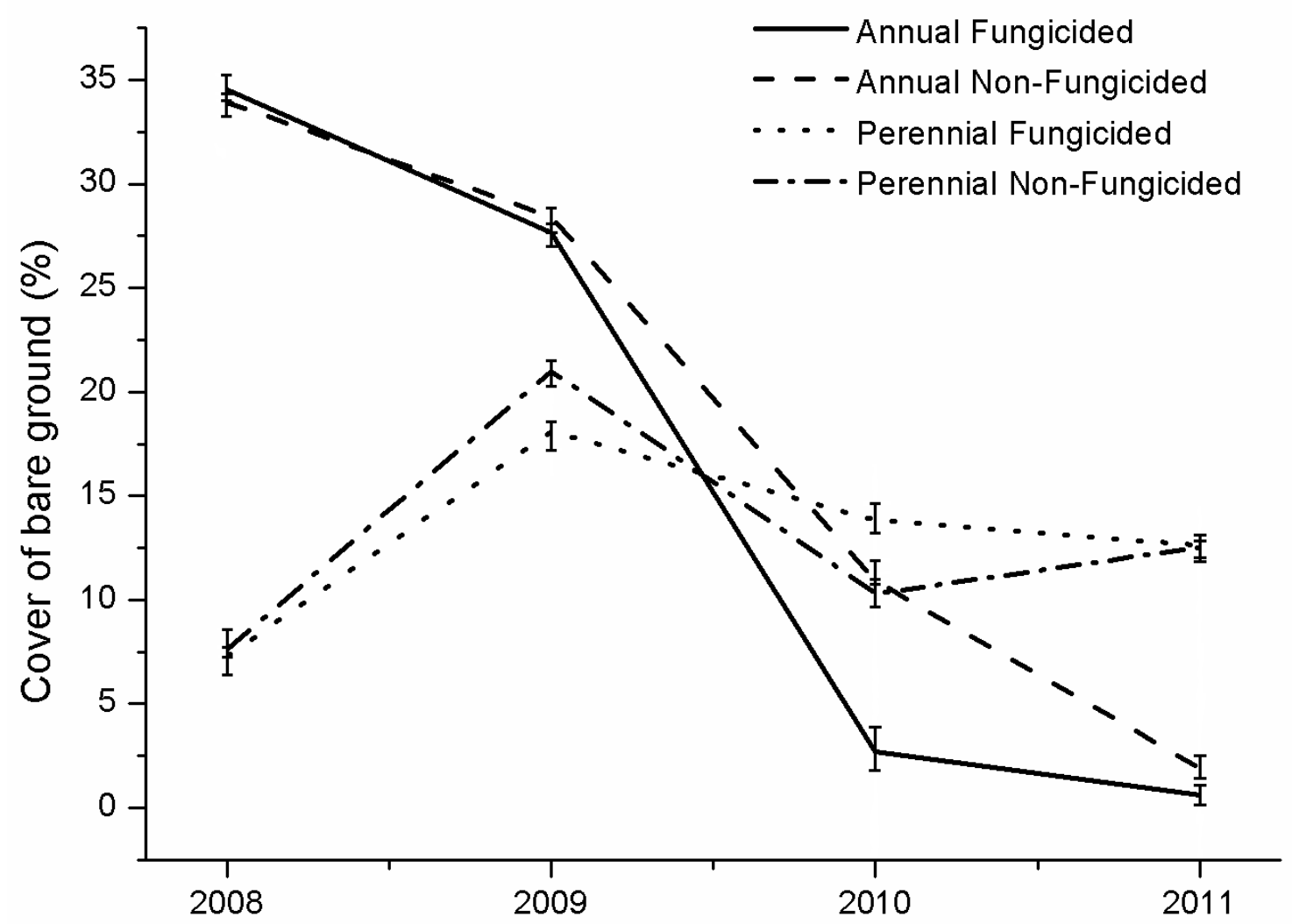

Figure 3. Changes in the coverage of bare ground from 2008-2011. Error bars represent S.E.M.

The quantity of litter also showed differences between the two experimental sites (Figure 4). At the initial stage we detected strong deviations $(\mathrm{t}=17.466 ; \mathrm{P}<0.001)$. At the annual-dominated site we observed $0 \%$ coverage of leaf litter, while at the perennial-dominated site the quantity was high (37\%). After the management had been stopped for the experiment, the litter content changed significantly at both sites. The coverage on the perennial-dominated site decreased in the second year, while the coverage of annual-dominated site increased. The coverage of leaf litter did not change 
in the last two years. This value varied around $20 \%$. Fungicide treatment did not affect this attribute at any of the experimental sites.

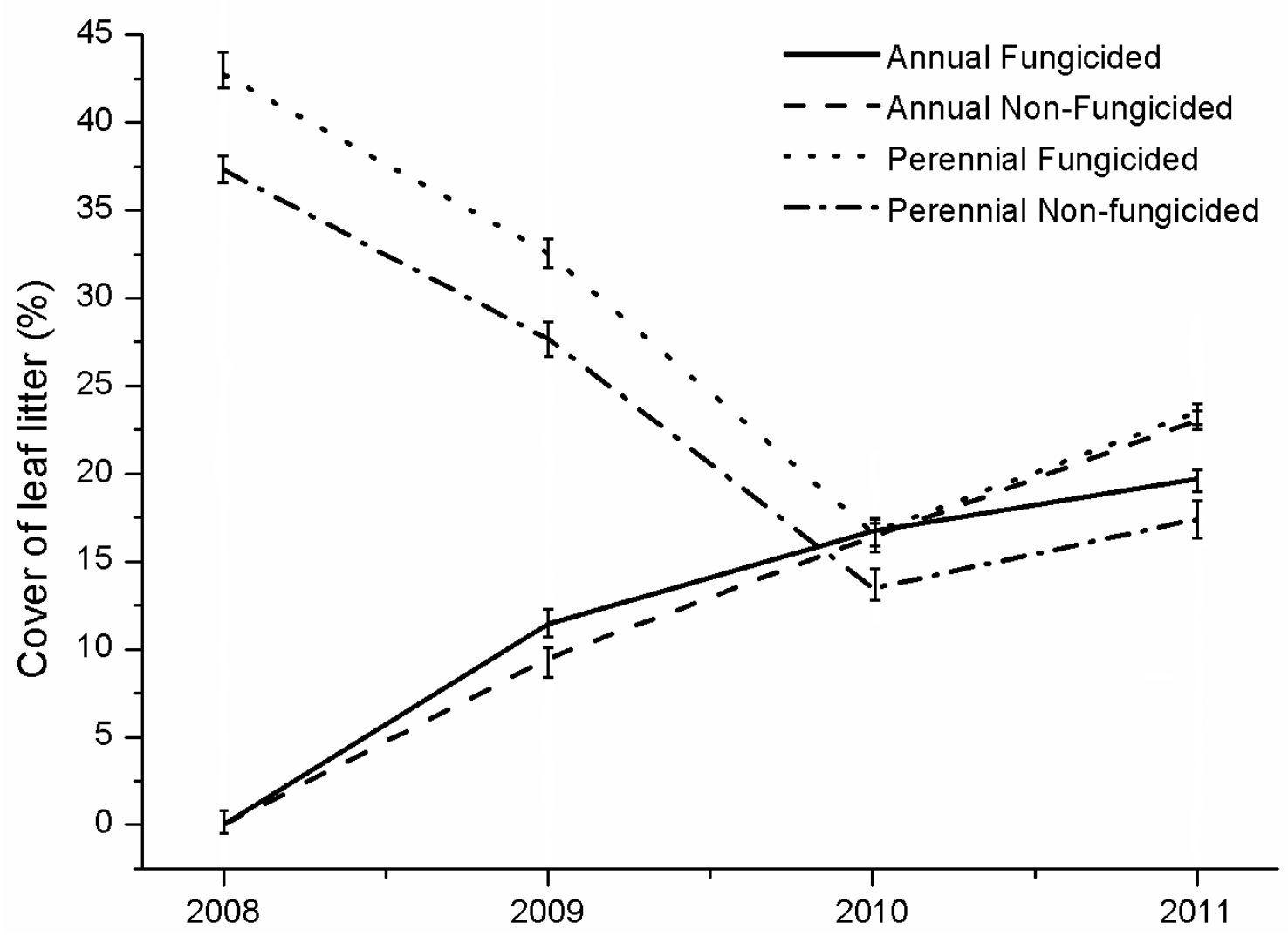

Figure 4. Changes in the coverage of leaf litter from 2008-2011. Error bars represent S.E.M.

\section{Discussion}

Our results show that the prevailing disturbance types of an area can significantly determine the later process of succession. Two sites were selected with different management history to conduct our experiment. These sites differed in their composition already in the initial phase. In the more heavily disturbed, annualdominated site, the dominance of annuals was stronger, while in the less disturbed, perennial-dominated site, the grass species were dominant in the first year. This could be explained by the stronger disturbance tolerance of annual forb species, which usually dominate pioneer sites, while perennial grasses are more sensitive to intensive disturbance (Wilcox, 1998; Vaszari and Kukorelli, 2010). Our results support the findings of Porcova and Wikler (2014), who explained the dominance of annuals over perennials with the extensive management of vineyards. In contrast, the annual mowing and grazing in the perennial-dominated site strengthened the perennial grass dominance and stabilized the community, by supporting their reproduction (Meckenzie et al., 2006; Gao et al., 2014).

After abandonment of sites, secondary succession started to change the structure of the communities differently. During the experimental time, on the annual-dominated site, the dominance of forbs decreased, while perennial grasses took over their place. It is essential, because grass cover has an important role in succession by stabilizing the community's structure in the early phase (Prach and Pysek, 2001). In contrast, at the 
perennial-dominated site, grass dominancy decreased, proportion of perennial forbs increased significantly and at the same time shrub species started to appear, showing a further step of its succession (Kahmen and Poschold, 2004).

Changing percentage of bare ground is also an important factor in the process of succession. Increasing and decreasing of gaps can open or even close the way to new occupants, helps the development of communities and the maintenance of inner dynamics (Zhang et al., 2012). In the perennial-dominated site, bare ground cover increased in the first year, by the alteration of structure which causes changes in dominance. During this period the coverage of forbs and grasses suppressed both promoting the later forb dominancy. To the third and fourth year the bare ground did not change further. In the annual-dominated site the reduction of bare ground is the consequence of the termination of intensive hoeing. The release from disturbance resulted the reduction of gaps, and nearly a 100\% plant coverage developed; (Fahey and Puettmann, 2007).

Change in the amount of leaf litter was similar, but had a different direction in the two sites. The lack of management caused leaf litter reduction in the second and third year in the perennial-dominated meadow, which is the result of the cessation of mowing. In contrast in the annual-dominated vineyard, the lack of soil surface disturbance resulted natural litter formation. The two sites with different history reached similar coverage, which suggests us a balanced quantity of litter. Composition of litter plays an important role in the development of communities by direct allelopathic effects of dead plant materials, which can alter species composition and dominancy of plant assemblages (Saito and Tsuyuzaki, 2012). Moreover it can influence the success of new occupants by altering the light and microclimatic conditions (Bosy and Reader, 1995), and also has strong impact on chemical and microbial composition of soils (Hobbie, 2015; Rinkes et al., 2014)

In our research we investigated the effect of fungicide treatment on the development of plant communities in the early phase of succession. We found a strong effect only in the case of the highly disturbed, annual-dominated community. As Jasper et al., (1991) showed, soil disturbance can have a significant impact on fungal communities, but this effect is strongly linked with the vegetation type. In disturbance-associated communities the fungal species richness can be largely explained by richness of plant species (König et al., 2010) and even by the quantity and quality of litter input into soil (Frossard et al., 2013). The fungicide treatment in our experiment had positive effects on forbs and negative effects on grass species. Here the soil fungi might have helped the expansion of grasses against forbs, which was also confirmed by McCain et al. (2011). Although these results contradict the findings of Gange et al., (1993), that clarifies the role of soil biota in the stabilization of forb species in the early succession. Dostálek et al., (2013) found that grass species are more independent from fungal diversity, while they assist perennial forb species in non-disturbed vegetation types. Similarly to his findings, in the less disturbed annual-dominated site we found higher forb density in non-fungicided plots, but the difference was not significant. Therefore our results and the scientific literature can highlight the soil fungal community can have different effects in highly and slightly disturbed communities, depending on its species composition. Along with our findings, it has to be mentioned that, we only found differences among the differently treated sites in the fourth year of the experiment. This finding suggests, that natural development of fungal community in soils, feed-back among vegetation and soil 
community jointly interacted with the applied treatment, and required a longer time to express in the vegetation composition (Wang et al., 2011; Cutler et al., 2014).

Our study revealed that different disturbance levels strongly influence early succession processes by altering initial composition. We detected significant changes in forb-grass ratio and also in other measured variables (bare ground and leaf litter coverage) during the experimental time. On the annual-dominated site the development resulted an increase in grass cover and a decrease in bare ground. In contrast the perennial-dominated site stepped into a new successional phase, which in the first period opened up, providing space for upcoming changes, including a decrease in grass dominancy, and an increase in forb dominancy, and an intensive shrub growth. Soil fungi appear to have a big impact on highly disturbed, annual-dominated communities, where they can decrease the dominance of annual forbs, resulting a more grass dominated assemblages. While in the less frequently disturbed site, perennial-dominated communities, and the soil community facilitates the dominance of forbs species.

Acknowledgements. Authors are thankful for the Department of Biological Sciences (Montana Tech of the University of Montana) to cover page charges. We also thank for Judit Nyulasi and Ernő Kovács for their help in the collection of field data.

\section{REFERENCES}

[1] Bihari, Z., Szalai, S., Bozó, L. (2009): Natural Environment - Climate. In: Kocsis, K., Schweitzer, F., editors. Hungary in Maps. - HAS Geographical Research Institute, Budapest, Hungary 45-50.

[2] Bosy, J.L., Reader, R.J. (1995): Mechanisms Underlying the Suppression of Forb Seedling Emergence by Grass (Poa pratensis) Litter. - Functional Ecology 9: 635.

[3] Burt, J. W., Clary, J. J. (2014): Initial disturbance intensity affects recovery rates and successional divergence on abandoned ski slopes. - Journal of Applied Ecology 53: 607615 .

[4] Chambers, J. M. (1992): Linear models. Chapter 4 of Statistical Models in S eds J. M. Chambers and T. J. Hastie, Wadsworth \& Brooks/Cole.

[5] Collins, B., Wein, G., Philippi T. (2001): Effects of disturbance intensity and frequency on early old-field succession. - Journal of Vegetation Science 12: 721-728.

[6] Crawley, M.J. (2014): Statistics: An Introduction Using R, 2nd Edition. - John Wiley and Sons, Chichester.

[7] Cutler, N. A., Chaput, D. L., van der Gast, C. J. (2014): Long-term changes in soil microbial communities during primary succession. - Soil Biology and Biochemistry 69: 359-370.

[8] Dostálek, T., Pánková, H., Münzbergová, Z., Rydlová1, J. (2013): The Effect of AMF Suppression on Plant Species Composition in a Nutrient-Poor Dry Grassland. - PLoS One 8: e80535.

[9] Dölle, M., Schmidt, W. (2009): The relationship between soil seed bank, above-ground vegetation and disturbance intensity on old-field successional permanent plots. - Applied Vegetation Science 12: 415-428.

[10] Drury, W.H., Nisbet, I.C.T. (1973): Succession. - Journal of the Arnold Arboretum 54: 331-368.

[11] Dunn, R.M., Mikola, J., Bol, R., Bardgett, R.D. (2006): Influence of microbial activity on plant-microbial competition for organic and inorganic nitrogen. - Plant and Soil 289: $321-334$. 
[12] Emery, S. M., Rudgers, J. A. (2012): Impact of competition and mycorrhizal fungi on growth of Centaurea stoebe, an Invasive Plant of Sand Dunes. - The American Midland Naturalist 167: 213-222.

[13] Fahey, R. T., Puettmann, K. J. (2007): Ground-layer disturbance and initial conditions influence gap partitioning of understorey vegetation. - Journal of Ecology 95: 1098-1109.

[14] Frossard, A., Gerull, L., Mutz, M., Gessner, M. (2013): Shifts in microbial community structure and function in stream sediments during experimentally simulated riparian succession. - FEMS Microbiology Ecology 84: 398-410.

[15] Gange, A.C., Brown, V.K., Sinclair, G.S. (1993): Vesicular-Arbuscular Mycorrhizal Fungi: A Determinant of Plant Community Structure in Early Succession. - Functional Ecology 7: 616-622.

[16] Gao, H., Gao, Y. B , He, X. D. (2014): Impacts of grazing and mowing on reproductive behaviors of Stipa grandis and Stipa krylovii in a semi-arid area. - Journal of Arid Land 6: 97-104.

[17] Goldberg, D.E., Werner, P.A. (1983): The Effects of Size of Opening in Vegetation and Litter Cover on Seedling Establishment of Goldenrods (Solidago spp.). - Oecologia 60: 149-155.

[18] Hobbie, S. E. (2015): Plant species effects on nutrient cycling: revisiting litter feedbacks. - Trends in Ecology and Evolution 30: 357-363.

[19] Hothorn, T., Bretz, F. \& Westfall, P. (2008): Simultaneous Inference in General Parametric Models. - Biometrical Journal 50: 346-363.

[20] Jasper, D.A., Abbott, L.K., Robson, A.D. (1991): The effect of soil disturbance on vesicular-arbuscular mycorrbizal fungi in soils from different vegetation types. - New Phytologist 118: 471-476.

[21] Kahmen, S., Poschold, P. (2004): Plant functional trait responses to grassland succession over 25 year. - Journal of Vegetation Science 15: 21-32.

[22] Király, G (ed) (2009): Új magyar füvészkönyv. Magyarország hajtásos növényei. Határozókulcsok. (New Hungarian herbal. The vascular plants of Hungary. Identification key). - Aggteleki Nemzeti Park Igazgatóság. Jósvafö.

[23] König, S., Wubet, T., Dormann, C.F., Hempel, S., Renker, C., Buscot, F. (2010): TaqMan real-timePCR assays to assess arbuscular mycorrhizal responses to field manipulation ofgrassland biodiversity: effects of soil characteristics, plant species richness, andfunctional traits. - Applied and Environmental Microbiology 76: 3765-75.

[24] McCain, K. N. S., Wilson, G. W. T., Blair, J. M. (2011): Mycorrhizal suppression alters plant productivity and forb establishment in a grass-dominated prairie restoration. - Plant Ecology 212: 1675-1685.

[25] McKenzie, F. R., Jacobs, J. L., Kearney, G. (2006): Effects of spring grazing on dryland perennial ryegrass/white clover dairy pastures. 2. Botanical composition, tiller, and plant densities. Australian Journal of Agricultural Research 57: 555-563.

[26] Mariotte, P., Meugnier, C., Johnson, D., Thébault, A., Spiegelberger, T., Buttler, A. (2013): Arbuscular mycorrhizal fungi reduce the differences in competitiveness between dominant and subordinate plant species. - Mycorrhiza 23: 267-277.

[27] Maron, J.L., Klironomos, J., Waller, L. Callaway, R.M. (2014): Invasive plants escape from suppressive soil biota at regional scales. - Journal of Ecology 102: 19-27.

[28] Mills, K.E., Bever, J.D. (1998): Maintenance of Diversity within Plant Communities: Soil Pathogens as Agents of Negative Feedback. - Ecology 79: 1595-1601.

[29] Muller, C.H. (1966): The Role of Chemical Inhibition (Allelopathy) in Vegetational Composition. - Bulletin of the Torrey Botanical Club 93: 332-351.

[30] Perry, G.L.W., Millington, J.D.A. (2008): Spatial modelling of succession-disturbance dynamics in forest ecosystems: Concepts and examples. - Perspectives in Plant Ecology, Evolution and Systematics 9: 191-210. 
[31] Porcova, L., Wikler J. (2014): he effect of the different vineyard management to composition of weed species. Conference MendelNet, 19-20th November 2014, Brno, Czech Republic. Book of articles p.: 90-94.

[32] Prach, K., Pyšek, P. (2001): Using spontaneous succession for restoration of humandisturbed habitats: Experience from Central Europe. - Ecological Engineering 17: 55-62.

[33] Prach, K., Řehounková, K., Lencová, K., Jírová, A., Konvalinková, P., Mudrák, O., Študent, V., Vaněček, Z., Tichý, L., Petř́ík, P., Šmilauer, P., Pyšek, P. (2014): Vegetation succession in restoration of disturbed sites in Central Europe: the direction of succession and species richness across 19 seres. - Applied Vegetation Science 17: 193-200.

[34] R DEVELOPMENT CORE TEAM. (2011): R: A language and environment for statistical computing. R Foundation for Statistical Computing, Vienna.

[35] Řehounková, K., Pracha, K. (2001): Life-history traits and habitat preferences of colonizing plant species in long-term spontaneous succession in abandoned gravel-sand pits. - Basic and Applied Ecology 11: 45-53.

[36] Reynolds, H.L., Packer, A., Bever, J.D., Clay, K. (2003): Grassroots ecology: plantmicrobe-soil interactions as drivers of plant community structure and dynamics. Ecology 84: 2281-2291.

[37] Rillig, M.C., Mummey, D.L. (2006): Mycorrhizas and soil structure. - New Phytologist 171: 41-53.

[38] Rinkes, Z. L., DeForest, J. L., Grandy, A. S,, Moorhead, D. L., Weintraub, M. N. (2014): Interactions between leaf litter quality, particle size, and microbial community during the earliest stage of decay. - Biogeochemistry 117: 153-168.

[39] Rydlová, J., Sýkorová, Z., Slavíková, R., Turis, P. (2015): The importance of arbuscular mycorrhiza for Cyclamen purpurascens subsp. immaculatum endemic in Slovakia. Mycorrhiza 25: 599-609.

[40] Saito, T. I., Tsuyuzaki, S. (2012): Response of riparian vegetation to the removal of the invasive forb, Solidago gigantea, and its litter layer. - Weed Biology and Management 12: 63-70.

[41] Schnitzer, S.A., Klironomos, J.N., Hille Ris Lambers, J., Kinkel, L.L., Reich, P.B., Xiao, K., Rillig, M.C., Sikes, B.A., Callaway, R.M., Mangan, S.A., van Nes, E.H., Scheffer, M. (2010): Soil microbes drive the classic plant diversity-productivity pattern. - Ecology 92: 296-303.

[42] Sikes, B.A., Maherali, H., Klironomos, J.N. (2012): Arbuscular mycorrhizal fungal communities change among three stages of primary sand dune succession but do not alter plant growth. - Oikos 121: 1791-1800.

[43] Van der Heijden, M.G.A., Boller, T., Wiemken, A., Sanders, I.R. (1998): Different Arbuscular Mycorrhizal Fungal Species Are Potential Determinants of Plant Community Structure. - Ecology 79: 2082-2091.

[44] Van der Heijden, M.G.A., Bardgett, R.D., van Straalen, N.M. (2008): The unseen majority: soil microbes as drivers of plant diversity and productivity in terrestrial ecosystems. - Ecology Letters 11: 296-310.

[45] Van der Heijden, M.G.A., Klironomos, J.N., Ursic, M., Moutoglis, P., Streitwolf-Engel, R., Boller, T., Wiemken, A., Sanders, I.R. (1998): Mycorrhizal fungal diversity determines plant biodiversity, ecosystem variability and productivity. - Nature 396: 6972 .

[46] Van der Putten, W.H, Mortimer, S., Hedlund, K., Van Dijk, C., Brown, V.K., Lepš, J., Rodriguez-Barrueco, C., Roy, J., Diaz Len, T.A., Gormsen, D., Korthals, G.W., Lavorel, S., Santa Regina, I., Smilauer, P. (2000): Plant species diversity as a driver of early succession in abandoned fields: a multi-site approach. - Oecologia 124:91-99.

[47] Vaszari, Sz., Kukorelli, G. (2010): Gyomcönológiai vizsgálatok a Pannonhalmi borvidéken kettő-, három- és négyéves szőlöültetvényekben. Magyar Gyomkutatás és Technológia 11:3-14. 
[48] Wang B., Liu G. B., Xue S., Zhu B. (2011): Changes in soil physico-chemical and microbiological properties during natural succession on abandoned farmland in the Loess Plateau. - Environmental Earth Sciences 62: 915-925.

[49] Waring, B. G., Averill, C., Hawkes, C. V., (2013): Differences in fungal and bacterial physiology alter soil carbon and nitrogen cycling: insights from meta-analysis and theoretical models. - Ecology Letters 16: 887-894.

[50] Zhang, M. Y., Huang, D., Wang, K., Zhang, Y. J., Wang, C. J., Wang, R. C., You, Y. L. (2012): Grassland gap effects on Elymus dahuricus Turcz. seedling emergence, survival and growth. - Journal of Arid Environments 77: 11-16.

\section{APPENDIX}

Appendix Table 1. Species list and location data of the annual-dominated site. Dominancy of each species in the initial year (2008) is marked $(+, 1,2)$

\begin{tabular}{|c|c|c|c|c|}
\hline Species name & Location & GPS $\left({ }^{\circ} \mathbf{N},{ }^{\circ} \mathbf{E}\right)$ & & \\
\hline & $\begin{array}{l}\text { Annual-dominated; } \\
\text { Máriagyüd }\end{array}$ & $\begin{array}{l}45.881500 \\
18.254238\end{array}$ & & \\
\hline \multicolumn{5}{|l|}{ Forb species } \\
\hline $\begin{array}{l}\text { Arenaria serpyllifolia } \\
\text { Capsella bursa- }\end{array}$ & 2 & & + & sporadic \\
\hline pastoris & 1 & & 1 & frequent \\
\hline Erigeron annuus & 2 & & 2 & dominant \\
\hline Fumaria officinalis & + & & & \\
\hline Galium aparine & 1 & & & \\
\hline Geranium pusillum & 1 & & & \\
\hline \multicolumn{5}{|l|}{ Holosteum } \\
\hline umbellatum & + & & & \\
\hline Lactuca serriola & 1 & & & \\
\hline Lamium purpureum & 2 & & & \\
\hline Myosotis arvensis & + & & & \\
\hline Stellaria media & 2 & & & \\
\hline Taraxacum officinale & 1 & & & \\
\hline Veronica arvensis & 1 & & & \\
\hline Veronica hederifolia & 1 & & & \\
\hline Veronica polita & 1 & & & \\
\hline Vicia angustifolia & 1 & & & \\
\hline Vicia grandiflora & 1 & & & \\
\hline \multicolumn{5}{|l|}{ Grass species } \\
\hline Bromus sterilis & 2 & & & \\
\hline \multicolumn{5}{|l|}{ Calamagrostis } \\
\hline epigeios & 1 & & & \\
\hline Cynodon dactylon & 1 & & & \\
\hline Elymus repens & 1 & & & \\
\hline Роа аппиа & 1 & & & \\
\hline Poa pratensis & 1 & & & \\
\hline Setaria viridis & 1 & & & \\
\hline
\end{tabular}


Appendix Table 2. Species list and location data of the perennial-dominated site. Dominancy of each species is in the initial year $(2008)$ marked $(+, 1,2)$

\begin{tabular}{lll}
\hline Species name & Location & GPS $\left({ }^{\circ} \mathbf{N},{ }^{\circ} \mathbf{E}\right)$ \\
\hline & Perennial-dominated; & 46.026577, \\
& Máriakéménd & 18.470698
\end{tabular}

Forb species

Achillea collina

Acinos arvensis

Agrimonia eupatoria

Ambrosia artemisiifolia

Arrhenatherum elatius

Artemisia vulgaris

Astragalus glycyphyllos

Carduus acanthoides

Carlina vulgaris

Centaurea banatica

Centaurea micranthos

Centaurea scabiosa agg.

Cerastium fontanum

Cerastium semidecandrum

Chondrilla juncea

Chrysanthemum leucanthemum

Cichorium intybus

Cirsium vulgare

Coronilla varia

Crataegus monogyna

Daucus carota

Dipsacus laciniatus

Erigeron annuus

Eryngium campestre

Euphorbia cyparissias

Euphorbia virgata

Galium mollugo

Galium verum

Glechoma hederacea

Hieracium pilosella agg.

Hypericum perforatum

Knautia arvensis

Lathyrus tuberosus

Linum austriacum

Medicago lupulina

Melilotus officinalis

Mentha arvensis

Mentha longifolia

Nonea pulla

Ononis spinosa

Picris hieracioides

Plantago lanceolata

Ranunculus acris

Ranunculus bulbosus

Rubus caesius

Salvia pratensis

1
+
+
+
+
+
+
+
+
+
1
1
+
+
+
+
+
+
+
+
+
+
+
+
+
+
+
+
+
+
+
+
+
+
+
+

$+\quad$ sporadic

1 frequent

2 dominant 
Taraxacum officinale

Thlaspi perfoliatum

$+$

Thymus glabrescens

Torilis arvensis

Tragopogon orientalis

Trifolium pratense

Valerianella locusta

Veronica chamaedrys ssp.

vindobonensis

Vicia angustifolia

Grass species

Alopecurus pratensis

Bromus hordaceus ssp.

hordaceus

Calamagrostis epigeios

Cynodon dactylon

Dactylis glomerata s.str.

Elymus repens

Koeleria cristata s.str.

Poa angustifolia

Poа аппиа
$+$

$+$

$+$

$+$

$+$

$+$

$+$

1

$+$

$+$

2

$+$

1

$+$

$+$

2

APPLIED ECOLOGY AND ENVIRONMENTAL RESEARCH 14(3): 281-295. http://www.aloki.hu • ISSN 15891623 (Print) • ISSN 17850037 (Online) DOI: http://dx.doi.org/10.15666/aeer/1403_281295 (c) 2016, ALÖKI Kft., Budapest, Hungary 